\title{
A Corpus-Based Study of Hypotactic and Paratactic Thematic Relations in English and Urdu Clause Complexes
}

\author{
Humaira Yaqub $^{1} \&$ Aleem Shakir ${ }^{2}$ \\ ${ }^{1}$ PhD Candidate, Department of Applied Linguistics, Government College University Faisalabad, Pakistan \\ ${ }^{2}$ Assistant Prof., Department of Applied Linguistics, Government College University Faisalabad, Pakistan \\ Correspondence: Humaira Yaqub, Department of Applied Linguistics, Government College University \\ Faisalabad, Pakistan. E-mail: mary_sayal_es@yahoo.com
}

Received: July 23, 2019 Accepted: September 20, 2019 Online Published: September 24, 2019

doi:10.5539/ijel.v9n5p430 URL: https://doi.org/10.5539/ijel.v9n5p430

\begin{abstract}
The present research inquires the paratactic and hypotactic thematic relations in terms of their grammatical realization, functional significance (Halliday, 1994) and thematic progression (McCabe, 1999). In the paratactic clause complexes, two or more independent clauses are joined by the coordinating conjunctions while in the hypotactic clause complexes, two or more independent and dependent clauses are joined by the subordinating conjunctions. The specific objectives of this research are: (1) to define the grammatical realization of paratactic and hypotactic thematic structures in the English and the Urdu texts, (2) to describe the functional significance of paratactic and hypotactic thematic structures particular to information flow and thematic progression in the English and the Urdu texts, and (3) to discuss how effectively the paratactic and hypotactic thematic structures in the English text have been translated into the Urdu text. The English text, Things Fall Apart by Chinua Achebe and its translated Urdu text, Bikharti Duniya by Ikram Ullah have been selected for this study. These texts have been annotated through the annotation scheme of UAM Corpus Tool (O'Donnell, 2008). The results reveal that the Urdu text uses multiple equivalents of conjunction either paratactic or hypotactic in the English text. Thematic progression patterns in both texts are mostly constant, linear and peripheral. The unmotivated displacement of paratactic and hypotactic themes causes ambiguity and change the information flow in the Urdu text. The present research is significant to support the systemic functional grammar of Urdu taking into account of English.
\end{abstract}

Keywords: paratactic, hypotactic, English, Urdu, corpus

\section{Introduction}

The present study deals with the paratactic and hypotactic thematic structures in the English text and its translated Urdu text. The texts are organized with grammatical units to make meaning in their particular contexts as Halliday (1994) comments that a language contains set of systems which the author or speaker chooses to express meaning. He further claims that language systems are functional components which correspond to three metafunctions. Among three metafunctions, the textual metafunction comprising the paratactic and hypotactic thematic structures is focused in the present research for investigation.

\subsection{Problem Statement}

In the field of systemic functional linguistics, no significant research has been conducted to analyze the textual metafunction in Urdu translation. This study fills the research gap by investigating the paratactic and hypotactic themes of textual metafunction in Urdu translation. Particularly, the interdependency of hypotactic and paratactic themes with its functional significance is identified in the English text and in its Urdu translation. These themes are also compared in terms of their information flow for which the patterns of thematic progression (McCabe, 1999) are applied.

\subsection{Research Objectives}

This research defines some objectives. The first objective is to identify the grammatical realization of paratactic and hypotactic thematic structures in the English and the Urdu texts. The second objective is to discuss the functional significance and information flow of paratactic and hypotactic thematic structures in the English and the Urdu texts. The last objective is to annotate the English and its translated Urdu texts to define the differences 
in frequency and to discuss how effectively the English paratactic and hypotactic themes have been translated into Urdu. Based on these objectives, this study is carried out with the following questions.

1) How the paratactic and hypotactic thematic structures are grammatically realized in the English and the Urdu texts?

2) What is the functional significance of paratactic and hypotactic thematic structures particularly with respect to thematic progression and flow of information in the English and the Urdu texts?

3) How effectively the paratactic and hypotactic thematic structures in the English text have been translated into the Urdu text?

To examine these questions, this research finds the postcolonial novel, Things Fall Apart with its Urdu translation, Bikharti Duniya as an appropriate dataset due to two reasons. Firstly, this novel got much importance as postcolonial literature because Achebe wrote this novel in the English language to describe the culture and express the feelings of Africans as a civilized nation. Actually, Achebe used an appropriate grammatical structure which can easily be translated into Urdu. So, this novel with its Urdu translation has been selected to check either its thematic structures of information have been translated without any ambiguity or not. Secondly, being a postcolonial novel, it has many events of disputes, inference, causal-conditions, time, place, manner etc. which interweave the clause complexes of a text by coordination and subordination. So, the paratactic and hypotactic thematic structures can be found and analyzed possibly.

\subsection{Limitations of the Research}

For the analysis, the present piece of research has delimited the paratactic thematic structures including only independent clauses and the hypotactic thematic structures including both independent and dependent clauses. Only those conjunctions which have been used in both texts are further analyzed. The conjunctions which are not found in the English and Urdu corpora have not been focused for thematic analysis. Also, the account of non-finite dependent clauses has not been given in detail in this study.

\subsection{Significance of the Research}

The scope of this research is to provide awareness to translators that they should follow the parameters of SFL to translate the English texts into Urdu. This research is believed to make readers understand how to grasp the meaning and information of some ambiguous translations of the English texts. This study enables the researchers to apply other metafunctions of SFL theory to Urdu translations and language as a whole.

\subsection{Research Hypotheses}

This study hypothesizes that the English and the Urdu texts have contrastive hypotactic and paratactic themes with reference to their grammatical realization and functional significance. It is assumed that the hypotactic and paratactic themes build contrastive information flow in the English and the Urdu texts. It is also presupposed that an unmotivated displacement of the hypotactic and paratactic themes in the Urdu translation creates ambiguity in structure, function and information flow. To check these hypotheses, the descriptive and quantitative research method has been adopted and elaborated in the method section.

\section{Literature Review}

This research presents the corpus-based investigation of the paratactic and hypotactic conjunctions as the textual themes of clause complexes in the English and its translated Urdu texts. The textual themes actually relate text to its context (Eggins, 2004) and they are operated at the clause complex level (Gerot \& Wignell, 1994). The textual themes are incorporated in a text as the structural conjunctions which Eggins (2004) refers to tactic i.e., paratactic and hypotactic, to link clauses together by occurring at the initial position of clauses. These tactic structures come from parataxis and hypotaxis. The parataxis links the elements of equal status while the hypotaxis binds the elements of unequal status (Halliday \& Matthiessen, 2014). The parataxis and the hypotaxis are two types of interdependency relations in which the former connects the clauses of parallel structure while the latter connects the clauses of subordinate structure (Halliday, 1994; Nida, 1982). Moreover, the paratactic and hypotactic structures are termed as logical (Halliday, 1994) linked by the structural conjunctions. Emilia (2014) refers the structural conjunctions to coordinating and subordinating conjunctions which combine two or more clauses in which the main clause is the core of massage or information while the other coordinating and subordinating clauses are peripheral units of information. The clause complexes are the grammatical and semantic units linked by the tactic and logico-semantic relations. As Halliday (1994) claims that a clause complex is probably the functional organization of a sentence. The clause complexes involve two types of structure: (1) multivariate and (2) univariate. The multivariate structure consists of different functional 
constituents (subject, finite, predicator etc.). In SFL, the multivariate structure is related to the ideational, interpersonal and textual metafunctions. The ideational metafunction discusses the clause complex in line with the parameters of transitivity, the interpersonal metafunction discusses it in terms of mood and residue, and the textual metafunction discusses it according to the sequence of theme and rheme. On the other hand, the univariate structure includes two or more equal functional elements (primary and secondary clauses). As Matthiessen et al. (2010, p. 235) claims "each new element is related to the previous simply as the 'next' link in a series or chain". Halliday (1994) proposed the following system of clause complexes.

\begin{tabular}{|c|c|c|}
\hline Types of taxis & <Primary clause $>$ & $<$ Secondary clause \\
\hline 1. Parataxis & 1 (initiating) & 2 (continuing) \\
2. Hypotaxis & $\alpha$ (dominant) & $\beta$ (dependent) \\
\hline
\end{tabular}

Figure 1. The system of clause complexes

The primary and secondary clauses of univariate structure are combined by two taxis: parataxis and hypotaxis. In parataxis, the initiating and continuing clauses are paratactic clauses joined by the coordinating conjunctions while in hypotaxis, the dominant and dependent clauses are hypotactic clauses joined by the subordinating conjunctions. These conjunctions determine a degree of interdependency among clauses. The paratactic clauses are marked by the numbers $(1,2,3,4$ etc.) while the hypotactic clauses are marked by using Greek letters $(\alpha, \beta, \gamma$ etc.). Furthermore, the paratactic and hypotactic maintain their logico-semantic relations composed of expansion and projection. The following table shows the system of taxis and logico-semantic relations proposed by Halliday and Matthiessen (2014).

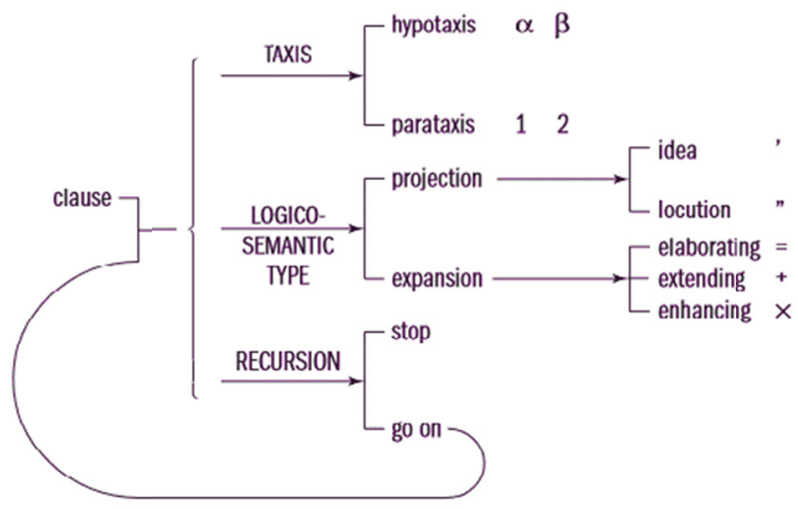

Figure 2. The system of taxis and logico-semantic relations

The expansion contains three types marked by the numerical symbols. The first type is elaboration marked by $(=)$, the second type is extension marked by $(+)$, and the third type is enhancement marked by $(\times)$. Projection is divided into two types: locution marked by (") and idea marked by ("). In the relationship of expansion, the secondary clause expands the meaning and information of the primary clause in three ways. Firstly, the coordinating or subordinating clause elaborates the meaning of the main clause by specifying or describing it. It is called paratactic elaboration including exposition, exemplification and clarification marked by $(1=2)$ or hypotactic elaboration marked by $(\alpha=\beta)$. Secondly, the coordinating or subordinating clauses extends the meaning of the main clause by addition, variation or alternation. This process is termed as paratactic extension notated by $(1+2)$ or hypotactic extension notated by $(\alpha+\beta)$. Thirdly, the coordinating or subordinating clause enhances the meaning of the main clause by reference of some circumstantial features: time, place, manner, condition, purpose, cause, concession, etc. This relationship is called paratactic enhancement notated by $(1 \times 2)$ or hypotactic enhancement notated by $(\alpha \times \beta)$. In the relationship of projection, the primary clause projects the secondary clause through the verbal process as locution or the mental process as an idea. The projection of locution is concerned with paratactic locution marked by the notation (1"2) or hypotactic locution marked by the notation $(\alpha " \beta)$ while the projection of an idea is associated with paratactic idea notated by $\left(1^{\prime} 2\right)$ or hypotactic idea notated by $\left(\alpha^{\prime} \beta\right)$. 
In Urdu, the system of parataxis and hypotaxis also deals with the primary and secondary clauses combined by conjunctions. Urdu uses the equivalents of English conjunctions to create paratactic and hypotactic thematic structures. Schmidt (1999) claims that Urdu coordinating conjunctions link two words, two phrases and two clauses of equal rank while subordinating conjunctions introduce subordinate clause with the subjunctive verb or the simple irrealis. The correlative coordinating and subordinating conjunctions are also used to link two or more Urdu clauses (Srivastav, 1991; Schmidt, 1999; Butt, King, \& Roth, 2007). Due to these possibilities of coordination and subordination, the system of Urdu clause complexes is somewhat similar to English as proposed by Halliday (1994). Only a few differences can be observed in Urdu paratactic and hypotactic themes due to major reasons: (1) pro-drop nature of Urdu, (2) free word order of Urdu and (3) clause final position of Urdu verbs. The Urdu clause complex is the combination of tactic and logico-semantic relations. In other words, Urdu can involve univariate clause structure composed of paratactic and hypotactic elements. And besides, Urdu can also create multivariate structure in terms of ideational, interpersonal and textual metafunctions in SFL. The textual metafunction focused for this study discusses theme-rheme structure of the Urdu clause complexes in contrast with English.

\subsection{Previous Studies}

Many studies have investigated the system of parataxis and hypotaxis in English and its translations in other languages. A large body of literature shows the comparison of English and Chinese languages in terms of parataxis and hypotaxis. Jiang (2008) investigated the English translation of a Chinese poem and observed the maximum occurrences of hypotactic thematic structures in English translation while the maximum occurrences of paratactic thematic structures in Chinese. She further claimed that English clauses are connected by connectives, propositions, verbs, pronouns, etc. but Chinese clauses mostly rely on semantic ties. Ma and Wei (2008) compared an English novel with its two Chinese translations and found that English hypotactic themes were translated into Chinese as paratactic themes and it happened due to difference in the nature of English and Chinese languages. These results are similar to the results of the study conducted by Jiang (2008). In another study, Harman (2010) examined the problems of non-defining relative clauses in English and its Chinese translation. He commented that in Chinese, non-defining relative clause precedes its noun while in English, non-defining relative clause follows its noun. Moreover, parataxis and hypotaxis were also identified in English and Arabic. In Arabic, the paratactic structures were used more frequently than hypotactic structures. As Marzari (2006) states that in Arabic, sentences follow each other by the use of coordinating conjunction. He further claimed that lined up paratactic conjunctions are particular to Arabic but not to English. Van Huffel (2007) examined the coordinating and subordinating conjunctions as themes in English and its translated fiction texts in Dutch. He claimed that these textual themes were translated as other themes which changed the meaning. Hasselgård (2004) investigated textual themes in terms of paratactic elaboration, extension and enhancement in translation of both English and Norwegian. He selected 1200 sentence pairs from the English Norwegian Parallel Corpus (ENPC) to find out differences. He found that some themes of enhancement were more frequent in Norwegian original text than in translation. The other themes of enhancement were less frequent in English original text than in translation. The next study was conducted by Rahnemoon, Ahangar and Nourmohammadi (2017) to identify the paratactic and hypotactic conjunctions as textual themes by creating a comparable Corpus (UTPECC) of 1000 English clauses and 1095 translated Persian clauses. His study concluded that the use of paratactic and hypotactic themes in Persian was more frequent than in English.

Along with the structure of paratactic and hypotactic textual themes, their thematic progression patterns (McCabe, 1999) have also been determined in this research. Some previous studies defined the thematic progression patterns. As the first work was conducted by Ventola (1995) to find thematic structures (textual, topical, and interpersonal) and thematic progression in translation. She studied and analyzed almost 19 instances and some paragraphs of thematic development and progression in the German scientific texts and their English translations. The results of her study showed that the some themes were translated as rhemes which created complications for the readers. She argued that translation choices affected the cohesion and rhetorical structures of German text due to negligence of the translators. McCabe (1999) investigated the corpus of 20 texts: 10 history textbooks published in the U.S. and 10 history textbooks published in Spain. She identified coordinators in textual themes with their thematic progression patterns through Chi-square and justified that the texts of both languages have overall similarity of coordinating conjunctions regarding text organization.

The thematic progression patterns were also investigated by Rørvik (2003) in conjunction with thematic structures. The researcher compared English scientific article and its 5 Norwegian translations. The study revealed that textual themes in English and Norwegian were different and different grammatical structures were used. In another study, Jalilifar (2009) investigated thematic development and progression in 9 English applied 
linguistics books and their translations in Persian. He identified structural themes as coordinators and subordinators. The results of his study showed that textual themes in Persian texts were counted higher than the themes in English texts. He asserts that the frequent use of textual themes made the Persian texts argumentative, impersonal, and objective. He presented no further explanation for the reasons behind the observed discrepancies between the source texts and the target texts. Alekseyenko (2013) carried out a research using three corpora of 3000 clauses of English National Geographic texts, their translated Russian texts and non-translated Russian texts on similar topics to compare and contrast their thematic structures. To identify textual connectivity of these texts, she focused on 13 types of textual connectors i.e., wh-element and conjunctions etc. along with the patterns of thematic progression. She applied one-way ANOVA test to compare the results of three corpora. After comparing the results, she found no significant difference regarding the use of conjunctions and thematic progression patterns in the three corpora due to their similar text type. Keeping in view of these studies, the present research discovers the grammatical and functional significance along with information flow and thematic progression of the paratactic and hypotactic themes from English corpus and its translated Urdu corpus.

\section{Method}

\subsection{Research Design}

To meet the hypotheses and objectives, the existing study employed the descriptive research method in conjunction with the quantitative research method. With regard to the descriptive method, the paratactic and hypotactic thematic structures in the English and the Urdu texts were realized in connection with their grammar, function and information. SFL provides a scheme and parameters of textual metafunction which not only involves a lexico-grammatical and logico-semantic analysis of paratactic and hypotactic themes (Halliday, 1994) but also specify their information flow applying the pattern of thematic progression (McCabe, 1999). To describe the grammatical realization, the functional significance and the thematic progression of paratactic and hypotactic themes, Halliday's (1994) and McCabe's (1999) interpretations were applied on the clause complexes opted from the English and its translated Urdu corpora. Besides such description, the quantitative method was applied to annotate the English and its translated Urdu corpora.

\subsection{Samples}

For the investigation of paratactic and hypotactic themes, the English text, Things Fall Apart by Chinua Achebe and its Urdu translation Bikharti Duniya by Ikram Ullah were selected as an appropriate dataset. The English text was downloaded from the Google scholar while the Urdu text was downloaded from the website, www.mashal.com.

\subsection{Corpus Size}

The English corpus contained approximately 50000 words and its translated Urdu corpus consisted of 55000 words. The whole corpora accumulated 105000 characters.

\subsection{Instrument}

In this research, the updated version of UAM Corpus Tool (O'Donnell, 2008) operated annotation of the corpora with the help of an annotation scheme which it either exports or allows the annotator to design his own scheme in line with the framework of SFL. O'Donnell (2008) confirms that this software offers a multiple-level annotation which served the objectives of the present research. The following annotation scheme displays all the themes of textual metafunction. 


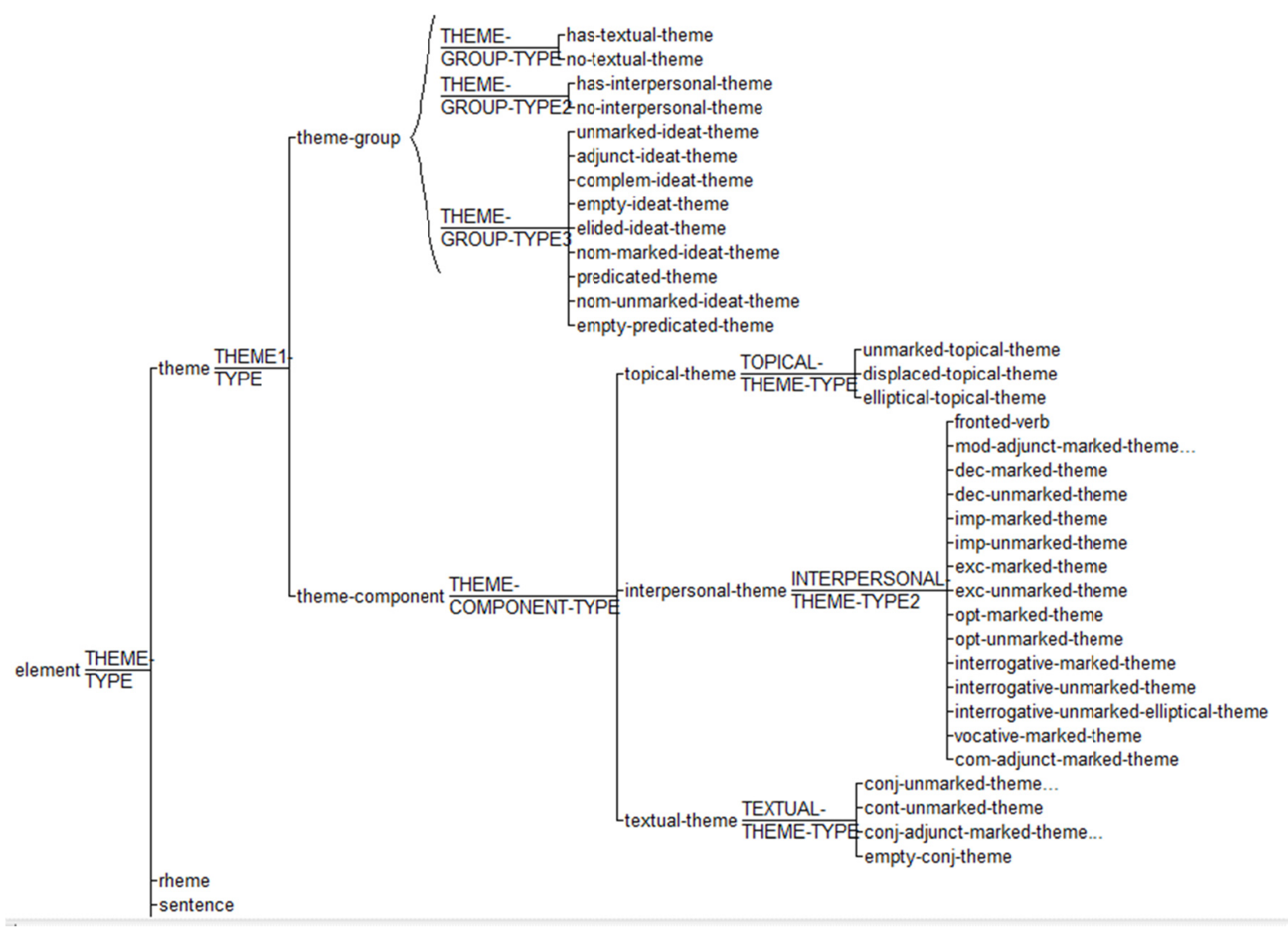

Figure 3. The annotation scheme of textual metafunction

From this scheme, only relevant annotation tags were assigned to the data of this research. After annotation process, the occurrences of paratactic and hypotactic themes in the English and the Urdu texts were counted to identify their differences. The patterns of thematic progression were also counted to check their variations. To trace out the reasons behind differences and variations, some clause complexes extracted from the English and the Urdu corpora were analyzed. To check information flow, four thematic progression patterns i.e., linear, constant, split theme, and split rheme proposed by McCabe (1999) were identified. The Linear thematic progression links the information of a theme-as-given to a preceding rheme-as-new. The constant thematic progression continues the information of a theme to be selected as the information of the following theme. The split theme and split rheme transfer their information into the two or more than two following themes. McCabe (1999) further claims that the themes which do not show any progression are termed as peripheral themes. The progression of themes was confirmed by some parameters i.e., semantic relations, identical words, synonymous expressions, possessive relationship, paraphrase, and semantic inference. Based on this method, the next sections cover the results and the discussion.

\section{Results}

\subsection{Grammatical Realizations of Paratactic and Hypotactic Themes}

This section discusses the grammatical realization of English and Urdu paratactic and hypotactic thematic structures. The English clause complexes joined paratactically indicate pronominal subjects either overt topical themes or ellipsed topical themes in the coordinating clause. The same is true to Urdu paratactic clause complexes. On the other hand, the English clause complexes joined hypotactically do not include any ellipsed topical themes in the subordinating clause. But the same is not true to Urdu hypotactic clause complexes because Urdu omits topical theme from the subordinating clause. To justify this point, the following clauses have been selected from the English and Urdu corpora.

1) a. The next morning, they were roasted in clay pots and then spread in the sun until they became dry and brittle.

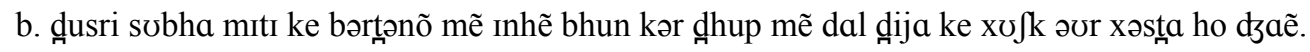

The next morning in clay pots, they, after roasting, were spread in the sun that (they) should become dry 
and brittle.

These clauses involve both paratactic and hypotactic themes. The English clause (1a) consists of two coordinating clauses which begin with an adjunct theme followed by a topical theme, and one subordinating clause which initiates with a hypotactic theme followed by a topical theme. The Urdu clause (1b) contains a non-finite dependent clause bhun kar (after roasting) along with independent clause which introduces two adverbial adjuncts i.e., dusri søbha (the next morning) and mitı ke bortanõ mẽ (in clay pots) followed by a topical theme inhẽ (they) at thematic position, and a subordinating clause ke xvjk avr xasta ho dzaẽ (that-become dry and brittle) which shows ellipsed topical theme vo (they). Here, the Urdu topical theme has been omitted from subordinating clause. It happens because instead of pronominal subjects, Urdu verbs specify the gender and number in clause complexes. Moreover, Urdu clauses do not accommodate ellipsed paratactic and hypotactic themes but the English clauses accommodate ellipsed hypotactic themes (relative pronouns). The subsequent clauses taken from English and Urdu corpora justify this.

2) a. You may have heard of the title I intend to take shortly.

b. mẽ dzo ləqəb dzəld hi Ixtejar kərne vala hũ ap ne uske bare mẽ suna to hoga.

The title which I intend to take shortly, you may have heard about that.

The English clause (2a) is composed of independent and dependent clause containing the ellipsed hypotactic theme which. This theme is not overt syntactically but semantically, it is clear that it is a relative clause including a relative conjunction. The Urdu clause (2b) is also composed of subordinating clause but it clearly mentions the relative pronoun dzo (which) in the first clause and its correlative pronoun oske (vo=that) in the second clause. The first Urdu clause looks like a nominalized theme but actually it is a subordinating clause combined to principle clause. Keeping in view of this point, it is obvious that Urdu uses correlative subordinating conjunctions in hypotactic thematic structures. Some specific pairs of correlative conjunctions mentioned in Table 3 have been identified in Urdu (Srivastav, 1991; Butt, King, \& Roth, 2007) but they are not common in English.

Another grammatical realization is related to the relative pronoun as hypotactic conjunction whose which shows possession regardless of gender specification in English. But Urdu uses its equivalents dFIs and dJIn as hypotactic conjunctions with necessary genitive case markers i.e., $k a, k e, k i$ which are inflected with number, gender and morphological form either nominative or oblique to modify the head noun (Butt \& King, 2004). Without these markers, the relative pronouns $d d_{3} I S$ and $d \xi I n$ lose the meaning and function of possession. So, the English hypotactic conjunction of enhancement whose has six possible equivalents in Urdu. Among six equivalents, the three i.e., dzIs ki (she whose), dzIs ka (he whose), dzIs ke (they whose) are gender specific, singular and sometimes non-living hypotactic themes in Urdu. The rest of equivalents i.e., dzIn $k i$ (she(s) whose), d ${ }_{3} I n k a$ (he(s) whose), dzIn ke (they(s) whose) are gender specific, plural and sometimes living hypotactic themes. These Urdu hypotactic themes are used according to the masculine/feminine, singular/plural and living/non-living status of their head nouns to translate the English hypotactic theme whose. The subsequent clauses selected from the English and Urdu corpora display this sequence.

3) a. Ezinma looked at her mother, whose eyes, sad and pleading, were fixed on her.

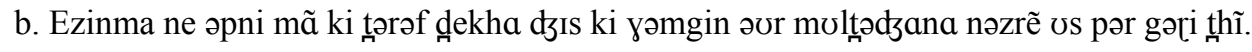

Ezinma looked at her mother whose sad and pleading eyes were fixed on her.

The English hypotactic theme whose in (3a) has converted into the hypotactic theme djIs ki (whose) marked by the feminine plural marker $k i$ in (3b). This marker is attached because of the feminine and plural nature of its head noun nəzrẽ (eyes) in Urdu. Moving to another grammatical realization, the English prepositional phrases are always translated as subordinating clause either at clause initial position or final position. It is justified by the below-mentioned clauses extracted from the English and Urdu corpora.

4) a. As for the boy himself, he was terribly afraid.

b. də̧əhã təak lərke ka taluq he vo buri tərha xofzəda tha

As far as the boy is concerned, he was terribly afraid.

The prepositional phrase as for in (4a) has no exact Urdu equivalent so; it is translated as a hypotactic thematic structure starting with a hypotactic theme dzaha tak (as far as). Moving to the next grammatical realization, it is observed that Urdu also involves some correlative conjunctions (Srivastav, 1991; Butt, King, \& Roth, 2007) which have been analyzed as correlative hypotactic themes in this study. Srivastav (1991) presented a pattern of correlatives composed of a demonstrative pronoun $v o$ and a relative pronoun dzo in Hindi-Urdu. Butt, King and 
Roth (2007) presented some other patterns i.e., dzIs-ðs (which-that) as an oblique form, dsahã-vahã (where-there) as a distal form, and djIdar-vdar (where-there) as a proximal form. These correlative themes are not common in English. The forthcoming clauses taken from the Urdu corpora are translated into English to define the nature of correlative hypotactic themes in both languages.

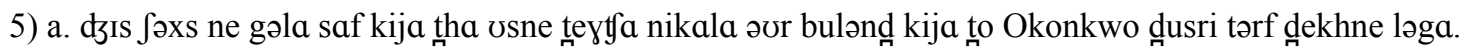

b. The man who cleared his throat, he drew up and raised his machete, then Okonkwo looked away.

6) a. țom ḑahã se ae ho kəja vahã jam nəhi ogate.

b. where you come from, do you not grow yams there?

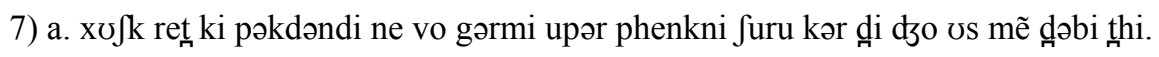

b. The dry, sandy footway began to throw up that heat which lay buried in it.

The correlative hypotactic themes djIs-os in (5a) can corresponds to its English equivalents who-he in translated clause (5b). The next hypotactic theme pairing dzahã-vahã in (6a) corresponds to its English equivalents where-there in (6b). The hypotactic theme pairing vo- dzo in (7a) corresponds to its translated equivalents that-which in (7b). Although these hypotactic pairings are not common in English, yet their English translation is possible. But after translation, these structures resemble nominalized themes and subordinating hypotactic themes. Even the correlatives in Urdu structures also resemble nominalized themes. It is an interesting point here that Urdu correlative themes can also be discussed as nominalized themes according to parameters of SFL. The next section interprets the functional significance and thematic progression of paratactic and hypotactic themes.

\subsection{Functional Significance \& Thematic Progression of Paratactic and Hypotactic Themes}

The paratactic and hypotactic thematic structures in English and Urdu imply similar functional significance. A thematic structure is generally divided into two parts: (1) theme which initiates a message as given information, and (2) rheme which is the remainder of a message as new information. The theme-rheme sequence conflated to given-new units of information in English is also followed by Urdu. The SOV Urdu structure indicates a subject conflated with topical theme at clause initial position. Urdu also includes clause complexes which are combined by coordinating and subordinating conjunctions. In Urdu, these conjunctions seem to be paratactic and hypotactic themes preceding topical themes like English. As Halliday (1994) puts forward that the paratactic and hypotactic conjunctions are unmarked themes preceding a topical theme. The topical theme is conflated with given information while the rheme is conflated with new information but the conflation of theme with new information is also possible (Halliday \& Matthiessen, 2014). The same is true to the thematic structure and the information flow in Urdu. Furthermore, Urdu has a tendency to displace wh-relative pronouns (Table 2) used as hypotactic themes in clause complexes. As Bayer (1996) claims that the displacement of wh-phrases is possible in Urdu if they are CPs. In other words, when wh-hypotactic themes follow topical themes in Urdu clause complexes, they are known as displaced hypotactic themes. And when wh-hypotactic themes precede topical themes in Urdu clause complexes, they are known as unmarked hypotactic themes. The succeeding clauses chosen from the English and Urdu corpora become a proof.

8) a. When Okonkwo arrived at Mbaino, he was treated with great honour and respect.

b. Okonkwo dzəb Mbaino pohntfa to ひske sath nəhajət Izət o ehtəram ka suluk kija gəja.

In (8a), the temporal hypotactic theme when is an unmarked theme which precedes the topical theme but its Urdu equivalent $d z a b$ is a displaced theme which follows the topical theme in (8b). This is common structure for wh-hypotactic themes in Urdu due to its flexible and free word-order. This displacement looks like the displacement of topical themes defined by Halliday and Webster (2014) in English. Here, the most interesting point is that despite being a displaced theme, it does not change its functions and meaning and remains a hypotactic conjunction. Additionally, Urdu displaces not only wh-hypotactic themes but also some other paratactic and hypotactic themes e.g., phir bhi (yet), Is ke bavadzud (yet), Islije (so), tovnantfa (therefore), dzab tak (until/unless) etc. without changing their functions or meaning. According to this discussion, it is obvious that English and Urdu paratactic and hypotactic thematic structures include same functions generally. But they can change their functions if they are involved in unmotivated displacement. The next section gives the detailed account of such cases. Besides this point, the next section analyzes that the change of thematic progression patterns in paratactic and hypotactic thematic structures depends on how and at what position the paratactic, hypotactic and topical themes are placed in English and in its Urdu translation to define the flow of given and new units of information. 


\subsection{Analysis of Paratactic and Hypotactic Thematic Structures}

The forthcoming tables show the difference in frequency of the English and Urdu paratactic and hypotactic themes and their thematic progression patterns. These themes have been classified according to their tactic and logic-semantic relations. The frequent paratactic and hypotactic themes in English text and in its Urdu translation are focused for further interpretation. In Table 1, the coordinating conjunctions as paratactic themes in English and Urdu have been counted.

Table 1. Coordinating conjunctions as paratactic themes

\begin{tabular}{|c|c|c|c|c|c|c|c|c|c|}
\hline \multirow{6}{*}{ Expansion } & \multirow{3}{*}{ Extension } & \multicolumn{2}{|l|}{ English } & \multicolumn{2}{|l|}{ Urdu } & \multicolumn{2}{|l|}{ English } & \multicolumn{2}{|l|}{ Urdu } \\
\hline & & And & $2173 \%$ & əor & $1594 \%$ & Else & $1 \%$ & vərna & $1 \%$ \\
\hline & & Yet & $3 \%$ & $\begin{array}{l}\text { phir bhi } \\
\text { Is ke bavadzud }\end{array}$ & $3 \%$ & But & $348 \%$ & $\begin{array}{l}\text { ləkın } \\
\text { məgər }\end{array}$ & $306 \%$ \\
\hline & & Except & $6 \%$ & masvae & $6 \%$ & Or & $128 \%$ & $\begin{array}{l}\text { ja } \\
\text { nəhĩ to }\end{array}$ & $77 \%$ \\
\hline & Enhancement & So & $81 \%$ & $\begin{array}{l}\text { Islije } \\
\text { ləhaza }\end{array}$ & $79 \%$ & For & $8 \%$ & krjũke & $2 \%$ \\
\hline & & Therefore & $7 \%$ & $\begin{array}{l}\text { to } \\
\text { tyonantfa } \\
\text { ləhaza }\end{array}$ & $5 \%$ & - & - & - & - \\
\hline \multirow[t]{2}{*}{ Projection } & Locution & Say, “_” & $391 \%$ & kəhna, “_” & $388 \%$ & Tell, “_” & $202 \%$ & bətana, " ", & $200 \%$ \\
\hline & Idea & Think, "_" & $154 \%$ & sotfna, “"” & $152 \%$ & Believe, "“” & $51 \%$ & jəkin kərna, “"” & $50 \%$ \\
\hline
\end{tabular}

This table shows either similar occurrence of coordinating conjunctions as paratactic themes or it is more frequent in English than Urdu. As Urdu can accommodate multiple equivalents of a single English coordinating conjunction so, the Urdu translation of English paratactic themes is possible in a number of ways. During the Urdu translation, some paratactic themes have been converted into hypotactic themes while the others have been omitted by separating the clauses. Due to such conversion and omission, Urdu text shows less frequent occurrence of paratactic themes. As a significant difference can be observed between the frequency of English paratactic theme and $2173 \%$ and its Urdu equivalent oor $1594 \%$. Another significant difference is found while comparing the frequency of English paratactic theme but 348\% with the frequency of their Urdu equivalents lakın and magar 306\%. Despite having two Urdu equivalents, the English paratactic theme but has been either

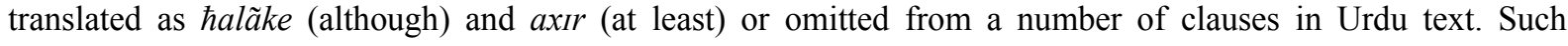
differences in translation create ambiguity in conveying the meaning of a particular paratactic theme. The similar case is observed with the translation of English paratactic theme or having 128\% frequency. This theme has the most appropriate Urdu equivalent $j a$ having $75 \%$ frequency. The multiple translation choices of the paratactic theme or are the reasons of this huge difference in frequency. This theme has been translated as na to-əvr na hi (neither-nor), agar-to (if-then), to kəhã (where else), avr (and), to kəja (what else) and nəhĩ to (otherwise). The translations choices to kəhã (where else) and to kaja (what else) convey the relevant meaning in situational context and can replace some other paratactic themes as well. The other paratactic themes i.e., for $8 \%$, therefore $7 \%$ and so $81 \%$ are also more frequent in English than Urdu. In Urdu text, their counterparts i.e., kijüke 2\%, tonantfa/lahaza 5\% and Islije/lahaza/to $79 \%$ are less frequent because of their omission during translation process. Furthermore, the paratactic themes of projection occur more frequently in English than Urdu because these have been translated as hypotactic themes of projection in the Urdu text. Keeping in view of these differences, it is found that the paratactic themes of expansion in terms of elaboration, extension and enhancement and the paratactic themes of projection in line with locution and idea make the English text more cohesive and meaningful than the Urdu text. The Table 2 displays the use of subordinating conjunctions as hypotactic themes. 
Table 2. Subordinating conjunctions as hypotactic themes

\begin{tabular}{|c|c|c|c|c|c|c|c|c|c|}
\hline \multirow[b]{2}{*}{ Expansion } & \multirow[b]{2}{*}{ Elaboration } & \multicolumn{2}{|l|}{ English } & \multicolumn{2}{|l|}{ Urdu } & \multicolumn{2}{|l|}{ English } & \multicolumn{2}{|l|}{ Urdu } \\
\hline & & Whenever & $11 \%$ & $\begin{array}{l}\text { dzəb bhi } \\
\text { dzəb kəbhi }\end{array}$ & $13 \%$ & Which & $105 \%$ & $\begin{array}{l}\text { dzo } \\
\text { dyIs ne }\end{array}$ & $66 \%$ \\
\hline & & For which & $3 \%$ & ḑIs ke lije & $2 \%$ & In which & $12 \%$ & d马IS mẽ & $15 \%$ \\
\hline & & From which & $3 \%$ & dzIs se & $20 \%$ & On which & $5 \%$ & dzIs/dzin pər & $6 \%$ \\
\hline & & Whose & $24 \%$ & 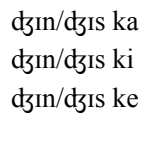 & $29 \%$ & Who & $141 \%$ & $\begin{array}{l}\text { dzo/ḋIn } \\
\text { dzIs ne } \\
\text { dżnhõ ne } \\
\text { ḑınhẽ }\end{array}$ & $82 \%$ \\
\hline & & Whatever & $2 \%$ & dzo kothh bhi & $2 \%$ & Whom & $13 \%$ & dzIs/dzIn ko & $15 \%$ \\
\hline & & When & $238 \%$ & dzob/dzIn & $248 \%$ & Where & $36 \%$ & dzəhã & $27 \%$ \\
\hline & & That & $75 \%$ & dzo & $190 \%$ & With which & $13 \%$ & $\begin{array}{l}\text { dəIIs ke sath } \\
\text { dəIIn se }\end{array}$ & $6 \%$ \\
\hline & Extension & While & $5 \%$ & dyobke & $7 \%$ & - & - & - & - \\
\hline & Enhancement & Until & $34 \%$ & dzəb tok & $12 \%$ & Unless & $9 \%$ & dzəb trak & $5 \%$ \\
\hline & & Since & $1 \%$ & tyũke & $3 \%$ & After & $8 \%$ & ke bad & $2 \%$ \\
\hline & & As far as & $2 \%$ & ḑəhã țək & $5 \%$ & Since & $9 \%$ & dzəbse & $2 \%$ \\
\hline & & As soon as & $29 \%$ & $\begin{array}{l}\text { dyũhi } \\
\text { ḑese hi }\end{array}$ & $19 \%$ & Before & $34 \%$ & $\begin{array}{l}\text { pəhle } \\
\text { peftror }\end{array}$ & $22 \%$ \\
\hline & & Even that & $0 \%$ & $\begin{array}{l}\text { hətake } \\
\text { jəhã tok ke }\end{array}$ & $8 \%$ & As if & $22 \%$ & $\begin{array}{l}\text { dzese ke } \\
\text { goja }\end{array}$ & $12 \%$ \\
\hline & & Because & $75 \%$ & krjũke & $68 \%$ & Such as & $2 \%$ & dzesa ke & $9 \%$ \\
\hline & & So that & $18 \%$ & ta ke & $31 \%$ & Even though & $2 \%$ & halãke & $1 \%$ \\
\hline & & Rather & $2 \%$ & bəlke & $41 \%$ & Till & $5 \%$ & tavəqtjeke/təak & $7 \%$ \\
\hline Projection & Locution & Say that & $139 \%$ & kəhna ke & $143 \%$ & Tell that & $118 \%$ & bətana ke & $129 \%$ \\
\hline & Idea & Think that & $95 \%$ & sotfna ke & $106 \%$ & Believe that & $82 \%$ & jəkin kərna ke & $97 \%$ \\
\hline
\end{tabular}

The hypotactic themes of expansion-elaboration combine relative subordinating clauses to matrix clauses. In English, the hypotactic themes of relative clauses take preposition while their Urdu equivalents take postpositions to convey the same meaning and information. Most of the English hypotactic themes can have more than one Urdu equivalents. As the table exhibits that the hypotactic theme which has two Urdu counterparts. The hypotactic theme which 105\% appears more frequently than its Urdu equivalents djo, djIs ne $66 \%$ because during translation, some relative subordinating clauses either have been converted into nominalized themes or have replaced their relative pronouns $d_{3}$, d d IS ne (which) with the relative pronoun ke (that). The same is true to the hypotactic theme who $141 \%$ which occurs more frequently in English than its equivalents dzo/dzin, djIs ne, dzInhõ ne, ḑınhẽ $82 \%$ in Urdu. Another English hypotactic theme where 36\% is more frequent than the Urdu hypotactic theme $d z \partial h \tilde{a} 27 \%$ due to its translation as nominalized theme. Such changes affect only the structure and information sequence but not the meaning of relative subordinating clauses. The next hypotactic theme from which 3\% is less frequent in English than its Urdu equivalent djIs se $20 \%$ because in the Urdu text, hypotactic theme djIs se has been used to translate not only the English hypotactic theme from which but also the theme with which. Such translation choices even do not affect meaning and information sequence of relative clauses. The next theme whose with $24 \%$ frequency have six Urdu equivalents with $29 \%$ frequency in the table but this is not a huge difference.

The hypotactic theme when $238 \%$ is less frequent in English than the hypotactic theme dzab $248 \%$ in Urdu because the equivalent $d z a b$ has been used to translate not only the temporal hypotactic themes when and as in most of the cases but also the hypotactic themes i.e., before and which in a few cases. In the former cases of translation, the meaning and information sequence remain the same but the latter translation choices affect the meaning to a great extent. Another remarkable difference in frequency is observed between the English theme until $34 \%$ and its Urdu equivalent dzab tak $12 \%$ because the theme until has been translated by the other hypotactic themes i.e., tavaqtjeke (till) and $\hbar$ take (even that) which causes to change the meaning of hypotactic clause. Moreover, the hypotactic finite clauses of the themes until and unless have been converted into non-finite clauses during translation. The frequency of the theme as far as is only $2 \%$ while its equivalent theme dzohã tak is 5\% because Urdu uses the same conjunction to translate the preposition as for. So, this preposition in English text has converted into a conjunction into Urdu text. The temporal hypotactic themes as soon as $29 \%$, before $9 \%$ and since $34 \%$ are either translated alternatively or become prepositions into Urdu so; these show low frequency. In the Table 3, the correlative conjunctions as paratactic and hypotactic themes have been counted. 
Table 3. Correlative conjunctions as paratactic and hypotactic themes

\begin{tabular}{|c|c|c|c|c|c|c|c|c|c|}
\hline \multirow{3}{*}{ Expansion } & \multirow[b]{2}{*}{ Elaboration } & \multicolumn{2}{|l|}{ English } & \multicolumn{2}{|l|}{ Urdu } & \multicolumn{2}{|l|}{ English } & \multicolumn{2}{|l|}{ Urdu } \\
\hline & & Which-that & $5 \%$ & dzIs-us & $17 \%$ & Where-there & $15 \%$ & dzahã-vahã & $43 \%$ \\
\hline & & When-then & $4 \%$ & dzəb-trəb & $5 \%$ & That-who & $19 \%$ & vo-dzo & $88 \%$ \\
\hline & & & & dzob-to phIr & & & & & \\
\hline & Extension & Not only-but & $6 \%$ & mehəz-bəlke & $17 \%$ & Although-yet & $21 \%$ & əgərfa-ləkın & $18 \%$ \\
\hline & & also & & na sirf-bəlke & & & & halãke-ləkın & \\
\hline & & Either-or & $1 \%$ & ja to-ja & $1 \%$ & Whether-or & $3 \%$ & tahe-ja & $3 \%$ \\
\hline & & Neither-nor & $7 \%$ & na to-əour na hi & $6 \%$ & If-then & $99 \%$ & əgər-toro & $94 \%$ \\
\hline & Enhancement & As-as & $10 \%$ & Itna-d3Itna & $13 \%$ & As-as & $25 \%$ & dzese-wese & $15 \%$ \\
\hline & & & & Itne-dzIttne & & & & dzesi-wesi & \\
\hline & & & & Itni-dJItni & & & & dzesa-wesa & \\
\hline & & So-that & $18 \%$ & Itna-ke & $20 \%$ & Lest-should & $3 \%$ & kəhĩ esa na ho & $3 \%$ \\
\hline & & Too-to & & & & & & & \\
\hline
\end{tabular}

The correlative conjunctions in English text are not only more frequent but also less frequent than their equivalents in Urdu text. The free word-order allows Urdu to accommodate correlative conjunctions in a number of ways. As the correlative not only-but also is translated into two ways with the percentage $17 \%$ while the correlatives so-that and too-to have only one possible equivalent with a little difference of percentage $20 \%$ in Urdu. Another correlative although-yet also has two Urdu equivalents having a little difference in percentage. The huge difference in frequency is observed between the Urdu correlative vo-dzo $88 \%$ and its English translation that-who $19 \%$ because this correlation is common in Urdu only and this becomes a nominalized

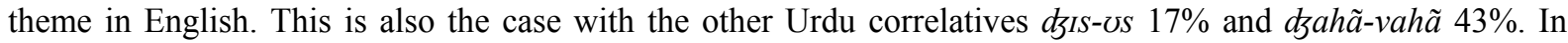
consideration of these occurrences, the Tables 4 and 5 exhibit thematic progression patterns. The four patterns of thematic progression have been calculated to check: (1) the position and function of paratactic and hypotactic themes, and (2) the position and function of topical themes which are connected by the paratactic and hypotactic themes. Simultaneously, the peripheral themes have also been counted in the tables of thematic progression to illustrate the difference in frequency.

Table 4. Thematic progression of paratactic and hypotactic themes in English text

\begin{tabular}{|c|c|c|c|c|c|c|}
\hline & & \multicolumn{5}{|c|}{ Thematic Progression } \\
\hline \multicolumn{2}{|c|}{ Taxis \& Logico-Semantic Relations } & Linear & Constant & Split & Split & Peripheral \\
\hline \multirow{6}{*}{ Expansion } & & & & & & \\
\hline & Hypotactic-elaboration & $379 \%$ & $125 \%$ & $7 \%$ & $0 \%$ & $211 \%$ \\
\hline & Paratactic-extension & $187 \%$ & $1764 \%$ & $24 \%$ & $0 \%$ & $710 \%$ \\
\hline & Hypotactic-extension & $22 \%$ & $96 \%$ & $0 \%$ & $0 \%$ & $10 \%$ \\
\hline & Paratactic-enhancement & $9 \%$ & $22 \%$ & $0 \%$ & $2 \%$ & $65 \%$ \\
\hline & Hypotactic-enhancement & $67 \%$ & $116 \%$ & $0 \%$ & $5 \%$ & $122 \%$ \\
\hline \multirow[t]{5}{*}{ Projection } & Paratactic-locution & $143 \%$ & $169 \%$ & $0 \%$ & $0 \%$ & $281 \%$ \\
\hline & Hypotactic-locution & $25 \%$ & $57 \%$ & $0 \%$ & $0 \%$ & $176 \%$ \\
\hline & Paratactic-idea & $21 \%$ & $82 \%$ & $0 \%$ & $0 \%$ & $102 \%$ \\
\hline & Hypotactic-idea & $16 \%$ & $32 \%$ & $0 \%$ & $0 \%$ & $129 \%$ \\
\hline & Overall Frequency & $869 \%$ & $2463 \%$ & $31 \%$ & $7 \%$ & $1806 \%$ \\
\hline
\end{tabular}

In this table, the description of thematic progression manifests that the English text encompasses 379\% linear thematic patterns of hypotactic-elaboration to make a systematic flow of information. Mostly, the hypotactic themes of elaboration placed at subject position are relative pronouns which create link with their relevant head noun. This head noun is the rheme of preceding principal clause. And when the topical themes placed as subjects follow hypotactic themes (relative pronouns), they bear $211 \%$ peripheral while and $125 \%$ continuous thematic progression. The paratactic themes of extension hold $1764 \%$ constant, $187 \%$ linear, and $710 \%$ peripheral topical themes. The maximum constant flow is the outcome of coordination among the preceding and following topical themes in the English text. On the contrary, the $710 \%$ paratactic themes of extension are involved in combining alternative topical themes at periphery. The next hypotactic themes of extension are counted with the frequency $96 \%$ of constant thematic progression which is higher than the frequency $22 \%$ of linear thematic progression and even only $10 \%$ topical themes are observed at periphery. Actually, most of the hypotactic themes are correlatives which extend the information by incorporating additive topical themes so; there is noticed continuous flow of 
information. The next paratactic themes of enhancement place the topical themes at periphery carrying the highest frequency $65 \%$ while the frequency $9 \%$ of linear thematic progression is lower than the frequency $22 \%$ of constant themes. This frequency is the outcome of those paratactic themes which infer the information from preceding clauses. Moreover, the frequency $122 \%$ of peripheral themes is higher than the frequency $116 \%$ of constant themes. This is not a huge difference in frequency so, it is obvious that both themes cause coherent information flow of the temporal, causal-conditional, spatial and manner relations. The next paratactic and hypotactic themes of locution and idea are calculated with the highest frequency of topical themes of periphery because in the clause complexes of idea and locution, mostly the new information flows from principal clause to subordinating clause. The lowest frequency of thematic progression is counted in split themes and split rhemes. Holding an opinion of this description, the English text employs the constant themes more frequently than the linear themes, split themes, split rhemes and peripheral themes. The subsequent table illustrates the thematic progression of Urdu paratactic and hypotactic thematic structures.

Table 5. Thematic progression of paratactic and hypotactic themes in Urdu text

\begin{tabular}{lllllll}
\hline \multirow{2}{*}{ Taxis \& Logico-Semantic Relations } & \multicolumn{2}{l}{ Thematic Progression } & & \\
\cline { 3 - 6 } Expansion & & $\begin{array}{l}\text { Linear } \\
\text { Theme }\end{array}$ & $\begin{array}{l}\text { Constant } \\
\text { Theme }\end{array}$ & $\begin{array}{l}\text { Split } \\
\text { Theme }\end{array}$ & $\begin{array}{l}\text { Split } \\
\text { Rheme }\end{array}$ & $\begin{array}{l}\text { Peripheral } \\
\text { Theme }\end{array}$ \\
& Hypotactic-elaboration & $499 \%$ & $135 \%$ & $7 \%$ & $0 \%$ & $227 \%$ \\
& Paratactic-extension & $149 \%$ & $1149 \%$ & $24 \%$ & $0 \%$ & $713 \%$ \\
& Hypotactic-extension & $26 \%$ & $89 \%$ & $0 \%$ & $6 \%$ & $9 \%$ \\
& Paratactic-enhancement & $8 \%$ & $21 \%$ & $0 \%$ & $2 \%$ & $57 \%$ \\
& Hypotactic-enhancement & $45 \%$ & $122 \%$ & $0 \%$ & $0 \%$ & $131 \%$ \\
& Paratactic-locution & $112 \%$ & $165 \%$ & $0 \%$ & $0 \%$ & $311 \%$ \\
& Hypotactic-locution & $21 \%$ & $60 \%$ & $0 \%$ & $0 \%$ & $191 \%$ \\
& Paratactic-idea & $19 \%$ & $28 \%$ & $0 \%$ & $0 \%$ & $155 \%$ \\
& Hypotactic-idea & $14 \%$ & $30 \%$ & $0 \%$ & $0 \%$ & $159 \%$ \\
& Overall Frequency & $827 \%$ & $1845 \%$ & $31 \%$ & $8 \%$ & $1953 \%$ \\
\hline
\end{tabular}

In this table, the illustration starts from hypotactic themes of elaboration which elaborate the information by incorporating 499\% linear thematic progression. Like English, the Urdu relative pronouns are placed as subjects. The paratactic themes of extension include $1149 \%$ frequency of constant themes which is higher than that of linear and peripheral themes. But the frequency $1149 \%$ is comparatively lower than the frequency $1764 \%$ in English because the English text indicates a number of coordinating conjunctions in clause complexes while the Urdu text disconnects the clauses by omitting coordinating conjunctions. On the other hand, the paratactic themes of extension accommodate the topical themes at periphery with almost similar frequency $710 \%$ in English and $713 \%$ in Urdu. On the other hand, the hypotactic themes of extension are involved in continuous selection of topical themes with $89 \%$ frequency. Like English, the Urdu are correlatives which correlate the information of preceding and following topical themes. The paratactic themes of enhancement show the 57\% projection of peripheral themes because they participate in inferring and deducing the information from preceding clauses. The hypotactic themes of enhancement also deal with the frequency $131 \%$ of topical themes at periphery. Like English, these Urdu themes cause coherent information flow of the temporal, causal-conditional, spatial and manner relations. The next Urdu paratactic and hypotactic themes of idea and locution accommodate topical themes at periphery more frequently than that of English because the Urdu text implies extra clauses of idea and locution which are not observed in English. Holding an opinion of this illustration, it is obvious that the Urdu text uses peripheral themes more frequently than the linear themes, constant themes, split themes and spilt rhemes. The subsequent tables analyze the clauses from the English and Urdu corpora. The first analysis shows the mismatch between the paratactic and hypotactic themes in the English and the Urdu texts.

EST: Early in the afternoon the first two pots of palm-wine arrived from Obierika's in laws. They were duly presented to the women, who drank a cup or two each, to help them in their cooking.

UTT: dopəhər ke xətm hote hi Obierika ke semdijõ ke hã se jam ki fərab ke do ghəre pohnty gəe əor vo bəd孔a

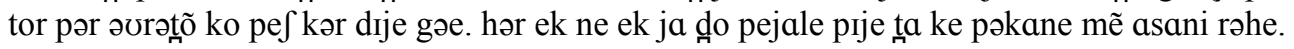


Table 6. Mismatch between the paratactic and hypotactic themes

\begin{tabular}{|c|c|c|c|c|c|}
\hline \multicolumn{6}{|c|}{ English Source Text } \\
\hline \multirow[t]{2}{*}{ CL } & \multirow[t]{2}{*}{$\mathbf{N}$} & \multicolumn{2}{|l|}{ Theme } & \multirow{3}{*}{$\begin{array}{l}\text { Topical } \\
\text { the first two pots of } \\
\text { palm-wine }\end{array}$} & \multirow[t]{2}{*}{ Rheme } \\
\hline & & Textual & Adjunct & & \\
\hline $1.1 \mathrm{a}$ & - & & Early in the afternoon & & arrived from Obierika's in-laws. \\
\hline $1.2 \mathrm{a}$ & - & & & They & were duly presented to the women, \\
\hline $1.3 \mathrm{a}$ & $\alpha=\beta$ & who & & & $\begin{array}{l}\text { drank a cup or two each, to help them in } \\
\text { their cooking. }\end{array}$ \\
\hline \multicolumn{6}{|c|}{ Urdu Target Text } \\
\hline CL & $\mathbf{N}$ & Theme & & & Rheme \\
\hline $1.1 \mathrm{~b}$ & - & Textual & $\begin{array}{l}\text { Adjunct } \\
\text { dopəhər ke xəț hote hi } \\
\text { Obierika ke semdijõ ke hã se }\end{array}$ & $\begin{array}{l}\text { Topical } \\
\text { jam ki Jərab ke do } \\
\text { ghəre }\end{array}$ & pohnty gəe \\
\hline $1.2 \mathrm{~b}$ & $1+2$ & ovr & & vo & bədza tor pər əurəțõ ko pe $\int$ kər dije gəe. \\
\hline $1.3 \mathrm{~b}$ & - & & & hər ek ne & ek ja do pejale prje \\
\hline $1.4 \mathrm{~b}$ & $\alpha \times \beta$ & ta ke & & pəkane mẽ & asani rəhe. \\
\hline
\end{tabular}

The English clause (1.1a) begins with a marked adjunct followed by a topical theme for which an unmarked pronominal theme is projected in the clause (1.2a). The translated Urdu clause (1.1b) is not an adjunct but a non-finite clause dopahar ke xatm hote hi (After ending midday) placed at thematic position along with an adjunct theme Obierika ke semdijõ ke hã se (from Obierika's in-laws) followed by a topical theme. This clause is joined to the next clause by a paratactic theme of extension. Although the English clause (1.2a) has not been joined to its preceding clause like Urdu clause (1.2b), yet the meaning and information of both the English and Urdu clauses are same. Furthermore, both clauses have constant thematic progression in terms of topical themes. But this sequence of topical thematic progression breaks in the next English relative clause (1.3a) which starts with a hypotactic theme of elaboration. The hypotactic theme is a relative pronoun at thematic position. It seems to project the information from the rheme of preceding clause to create linear thematic progression pattern. The translated Urdu clause (1.3b) begins with a topical theme. Like English, it also seems to project information from the rheme of preceding clause. But a big difference is observed regarding the non-finite clause in the rheme of English clause (1.3a) which has been translated as subordinating clause (1.4b) by using hypotactic theme of enhancement in Urdu. The hypotactic theme ta ke (so that) and its correlative verb rahe (may) give the sense of probability while the English non-finite clause to help does not give the sense of probability. The writer of source text in his own context seems to believe that palm-wine will certainly help women in their cooking while the writer of target text belongs to different context. He seems to be uncertain about the energy of palm-wine so, he translates the clause with the sense of probability. In fact, the Urdu theme pəkane me (cooking) in (1.4b) placed at periphery position creates ambiguity in meaning and information. To avoid ambiguity, the other

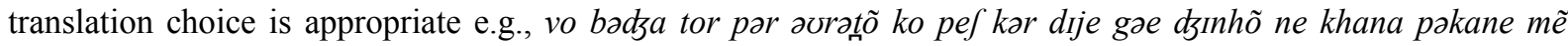
asani ke lije ek ja do pejale pije. The next clauses discuss how an additional Urdu clause affects the structure, meaning and thematic progression of its following clauses.

EST: Okonkwo said yes very strongly, so his chi agreed. And not only his chi but his clan too, because it judged a man by the work of his hands.

UTT: Okonkwo ne nehajət zor dar tərike se hã kəhi, to Is ke tyi ko bhi mane bəgher tfara na rəha. jũ kəhna tahije ke na sırf is ka tfi bəlke pura kəbila man gəja, kijũke Inke hã hər admi ko Iske hath ke kije kam se pərəkhte the. 
Table 7. The omission or addition of paratactic and hypotactic themes

\begin{tabular}{|c|c|c|c|c|c|}
\hline \multicolumn{6}{|c|}{ English Source Text } \\
\hline \multirow[t]{2}{*}{$\mathbf{C L}$} & \multirow[t]{2}{*}{$\mathbf{N}$} & \multicolumn{3}{|l|}{ Theme } & \multirow[t]{2}{*}{ Rheme } \\
\hline & & Textual & & Topical & \\
\hline $2.1 \mathrm{a}$ & - & & & Okonkwo & said yes very strongly, \\
\hline $2.2 \mathrm{a}$ & $1 \times 2$ & so & & his chi & agreed. \\
\hline $2.3 \mathrm{a}$ & $1+2$ & $\begin{array}{l}\text { And } \\
\text { not only }\end{array}$ & & his chi & --- \\
\hline $2.4 \mathrm{a}$ & $1+2$ & but & & his clan & too, \\
\hline $2.5 \mathrm{a}$ & $\alpha \times \beta$ & because & & it & judged a man by the work of his hands \\
\hline \multicolumn{6}{|c|}{ Urdu Target Text } \\
\hline \multirow[t]{2}{*}{ CL } & $\mathbf{N}$ & Theme & & & Rheme \\
\hline & & Textual & Adjunct & Topical & \\
\hline $2.1 b$ & - & & & Okonkwo ne & nehajər zor dar tərike se hã kəhi, \\
\hline $2.2 \mathrm{~b}$ & $1 \times 2$ & to & & us ke tyi & ko bhi mane bəgher tfara na rəha. \\
\hline $2.3 \mathrm{~b}$ & - & & & jũ & kəhna tyahrje \\
\hline \multirow[t]{2}{*}{ 2.4b } & $\alpha “ \beta$ & ke & & Is $\mathrm{ka} \mathrm{tg}^{\mathrm{i}}$ & --- \\
\hline & $1+2$ & na sirf & & & \\
\hline $2.5 \mathrm{~b}$ & $1+2$ & bəlke & & pura kəbila & man goja, \\
\hline 2.6b & $\alpha \times \beta$ & kijũke & Inke hã & hər admi ko & Iske hath ke kije kam se pərəkhte the. \\
\hline
\end{tabular}

The clause (2.1a) is an independent clause starting with a topical theme Okonkwo for which possessive adjective is used as the topical theme of following clause joined by a paratactic theme of enhancement. The same is true to the translated Urdu clauses (2.1b) and (2.2b). The difference of thematic structure, meaning and information is observed between the English clause (2.3a) and the Urdu clause (2.3b). The English clause (2.3a) has two paratactic themes of extension i.e., and which shows addition and not only which correlates its independent clause with the following independent clause (2.4a) starting with the paratactic theme but. These English clauses have been translated into Urdu clauses (2.4b) and (2.5b) joined by the paratactic correlative themes i.e., $n a$ sirf (not only) and balke (but also). But these Urdu clauses have been made the part of an Urdu subordinating clause (2.4b) which has the hypotactic theme of locution ke ([said] that) at clause initial position. Such sequence is the outcome of an additional clause (2.3b) which is not found in English. Due to this additional clause, the meanings have become ambiguous and the information focus in terms of thematic progression has been changed. The Urdu clause jũ kəhna tahije (it should be said) seems to negate and explain the meaning and information in the preceding clauses. This clause also interrupts the information flow and thematic progression. So, it should be removed to avoid ambiguity. Furthermore, the English topical theme Okonkwo as given information is selected continuously for the next three clauses. But the Urdu topical theme Okonkwo is interrupted by the peripheral theme $j \tilde{u}$ (it) in (2.3b). The next English hypotactic theme because in (2.5a) introduces a clause of reason and it is dependent on its preceding matrix clause. This clause has been translated as the Urdu clause (2.6b) with an adjunct at thematic position which affect thematic progression by placing the topical theme har admi ko (every man) as new information at periphery and the adjunct theme mke hã (in their clan) as given information because it is connected to the theme of preceding topical theme pura kabila (the whole clan). Due to this modification, the element a man of information focus in the rheme of clause (2.5a) becomes the theme-as-new in the clause (2.6b). The succeeding clauses show that the overlapping of paratactic themes creates ambiguity in meaning and changes the information flow of topical themes.

EST: The yams were then staked, first with little sticks and later with tall and big tree branches. The women weeded the farm three times at definite periods in the life of the yams, neither early nor late.

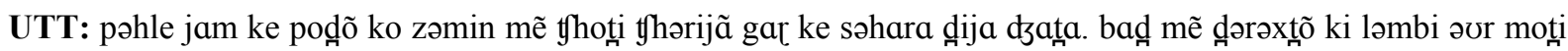

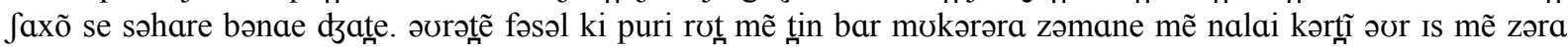

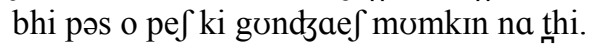


Table 8. The overlapping of paratactic themes

\begin{tabular}{|c|c|c|c|c|c|}
\hline \multicolumn{6}{|c|}{ English Source Text } \\
\hline \multirow[t]{2}{*}{$\mathbf{C L}$} & \multirow[t]{2}{*}{$\mathbf{N}$} & \multicolumn{3}{|l|}{ Theme } & \multirow[t]{2}{*}{ Rheme } \\
\hline & & Textual & Topical & & \\
\hline $3.1 \mathrm{a}$ & - & & The yams & & were then staked, first with little sticks \\
\hline 3.2a & $1+2$ & and & --- & & later with tall and big tree branches. \\
\hline 3.3a & - & & The women & & $\begin{array}{l}\text { weeded the farm three times at definite periods in the } \\
\text { life of the yams, }\end{array}$ \\
\hline 3.4a & $1+2$ & neither & --- & & early \\
\hline $3.5 \mathrm{a}$ & $1+2$ & nor & --- & & late. \\
\hline \multicolumn{6}{|c|}{ Urdu Target Text } \\
\hline \multirow[t]{2}{*}{$\mathbf{C L}$} & $\mathbf{N}$ & Theme & & & Rheme \\
\hline & & Textual & Adjunct & Topical & \\
\hline 3.1b & - & & pəhle & jam ke pod̃̃ ko & zəmin mẽ thotit thərijã gar ke səhara dija dzatăa. \\
\hline $3.2 b$ & - & & 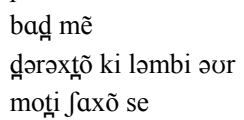 & səhare & bənae dzate. \\
\hline $3.3 \mathrm{~b}$ & - & & & əurə⿹𠃌丨 & $\begin{array}{l}\text { fəsəl ki puri rơt mẽ tin bar mokərəra zəmane mẽ } \\
\text { nalai kərtĩ }\end{array}$ \\
\hline 3.4b & $1+2$ & əor & Is mẽ & $\begin{array}{l}\text { zəra bhi pəs-o-pe } \int \mathrm{ki} \\
\text { gondzae } \int\end{array}$ & momkın na thi. \\
\hline
\end{tabular}

This table displays that the topical theme in (3.1a) is selected as the ellipsed topical theme in (3.2a) and these thematic structures of given information are joined by the paratactic theme of extension. These English themes have been translated with adjuncts at thematic position. The adjunct theme prhle (first) in (3.1b) and the adjunct theme daraxtõ ki lambi avr moti faxõ se (with tall and big tree branches) maintain the contextual meaning as in their English clauses but these translation choices affect the information flow and thematic progression because the rhemes as new information of English clauses covert into themes as new information of Urdu clauses. The next English independent clause (3.3a) including a topical theme at periphery is connected to the following independent clauses (3.4a) and (3.5a) which indicate ellipsed topical themes as given information selected from preceding theme in (3.3a). On the contrary, the translated independent clause (3.3b) starting with topical theme avratte (the women) as new information connects its meaning to the following independent clause which places an adjunct and a topical theme at thematic position as new information. The adjunct theme is me (in this) and the topical theme zara bhi pas-o-pe ki gondzae (not a little hesitation) convey not only ambiguous meaning but also build different thematic progression pattern as compared to the ellipsed topical themes in English. As the English clauses (3.4a) and (3.5a) convey the information that the women weeded the farm three times at definite periods in the life of the yams only. They did not weed the farm earlier than the definite period. And even they did not weed the farm later than the definite period. This information gives a sense that there is a specific time to grow yams. But the translated Urdu clause (3.4b) includes the information that the women weeded the farms three times at definite period and no hesitation was possible in weeding the farm. The topical theme pas-o-pes means hesitation. Although in a few Urdu contexts, this theme can give the meaning of before and after, yet it creates ambiguity because the noun pas-o-pe $\int$ mostly promotes an idea and sense of hesitation. The thematic progression patterns of the clauses (3.4a) and (3.5a) are continuous while the clause (3.4b) places topical theme at periphery and the adjunct shows linear connection with the rheme of preceding clause. To remove ambiguity and difference, another possible translation choice can be used e.g., na hi vo jam ki fasal ki rot se pahle avr na hi is ke bad nalai kərti thĩ or it can be further modified e.g., na hi vo jam ki fasal ki rot se pahle nalai kərti thĩ avr na hi is ke bad krrtti thĩ. In the following table, the three English clauses have been translated into five Urdu clauses in which one clause conveys extra information.

EST: They came in the cold harmattan season after the harvests had been gathered, and ate up all the wild grass in the fields.

UTT: sərd్ ke mosəm mẽ ḑəb fəsəl ki kətai ho tfuki hoți əor hơfk gərd alud səhrai həvafumal məfrrk se fəl rəhi hoți, tədi ați əor khețõ mẽ ugi səb ki səb d’əngli ghas hərə̧p kər dzați. 
Table 9. The paratactic clauses of extra information

\begin{tabular}{|c|c|c|c|c|c|}
\hline \multicolumn{6}{|c|}{ English Source Text } \\
\hline \multirow[t]{2}{*}{$\mathbf{C L}$} & \multirow[t]{2}{*}{$\mathbf{N}$} & \multirow{2}{*}{$\begin{array}{l}\text { Theme } \\
\text { Textual }\end{array}$} & & & Rheme \\
\hline & & & \multicolumn{2}{|l|}{ Topical } & \\
\hline 4.1a & - & & \multicolumn{2}{|l|}{ They } & came in the cold harmattan season \\
\hline $4.2 \mathrm{a}$ & $\alpha \times \beta$ & after & \multicolumn{2}{|c|}{ the harvests } & had been gathered, \\
\hline $4.3 \mathrm{a}$ & $1+2$ & and & \multicolumn{2}{|c|}{---} & ate up all the wild grass in the fields. \\
\hline \multicolumn{6}{|c|}{ Urdu Target Text } \\
\hline $\mathbf{C L}$ & $\mathbf{N}$ & Theme & & & Rheme \\
\hline $4.1 \mathrm{~b}$ & $\alpha \times \beta$ & $\begin{array}{l}\text { Adjunct } \\
\text { sərd్ri ke } \\
\text { mosəm mẽ }\end{array}$ & $\begin{array}{l}\text { Textual } \\
\text { dyəb }\end{array}$ & $\begin{array}{l}\text { Topical } \\
\text { fəsəl ki kətai }\end{array}$ & ho tyuki hoti \\
\hline 4.2b & $1+2$ & & our & $\begin{array}{l}\text { hojk gərd alud } \\
\text { səhrai həva }\end{array}$ & 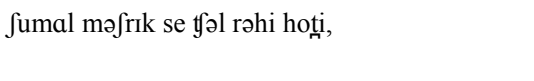 \\
\hline $4.3 \mathrm{~b}$ & - & & & tədi & ati \\
\hline 4.4b & $1+2$ & & əor & --- & $\begin{array}{l}\text { khețõ mẽ ugi səb ki səb ḑəngli ghas hərəp kər } \\
\text { ḑati. }\end{array}$ \\
\hline
\end{tabular}

The analysis starts from the English clause (4.1a) which includes the unmarked ideational theme as given information and the rheme as an information focus. On the contrary, the translated clause (4.1b) exhibits adjunct theme as new information, textual theme as given information and topical theme as new information at thematic position. This translation choice is ambiguous because it seems to convey the information that the harvests had been gathered in the cold harmattan season while the English clause (4.1a) informs that the locusts came in the cold harmattan season. This information is continued by the subordinating English clause (4.2a) which discusses that after the harvests had been gathered, they (locuts) came in the cold harmattan season. The information of Urdu clause (4.1b) is extended by the principal clause (4.3b). However, the English clauses give the idea that locusts came in the harmattan season which starts after harvesting the crops while the Urdu clauses show that in the harmattan season, the harvests had been gathered and the locusts also came. Furthermore, the temporal hypotactic theme after specifying a different time for two or more actions is translated as the temporal hypotactic theme $d z a b$ (when) specifying a similar time for two or more actions. This translation choice also create ambiguity in the clauses (4.1b) and (4.3b). The next Urdu clause (4.2b) is attached to its preceding subordinating clause but it seems an additional information which overlaps and delays the information in the following clause (4.3b). To avoid ambiguity and delay in information, these clauses can have some other translation choices e.g., (1) fasal ki katai ho ḑane ke bad xujk avr gard alud mosam mẽ tedi ati, (2) tedi fasal ki katai ho ḑane ke bad xvjk avr gard alud mosam mẽ atti, (3) fasal ki katai ho dzane ke bad tedi xvjk avr gard alud mosam mẽ atti. These translations convey information that after the harvesting, locusts came in the cold harmattan season. In these translations, the non-finite clause fasal ki katai ho dzane ke bad (after the harvesting) has been used. It justifies that the English subordinating clause of hypotactic theme after is always translated as a non-finite clause in Urdu. The next English clause (4.3a) with an ellipsed theme is an independent clause which is linked with both preceding clauses. This English clause has been translated as the Urdu clause (4.4b) with the similar meaning, information focus and thematic progression. The subsequent clauses discusse that the placement of adjunct before the correlative hypotactic themes in Urdu causes an ambiguous structure.

EST: To crown it all he had taken two titles and had shown incredible prowess in two inter-tribal wars. And so, although Okonkwo was still young, he was already one of the greatest men of his time. Age was respected among his people, but achievement was revered.

UTT: In səb se bərh kər jəh ke vo do ləqəb Ixtəjar kər tyuka tha əor qəbaeli ke maben doḑə̃gõ mẽ naqabile jəqin quvəț-o-taqət ka muzahıra kər ffoka tha. Okonkwo əbhi ḑəvan tha ləkın us ka Jumar əpne zəmane ke

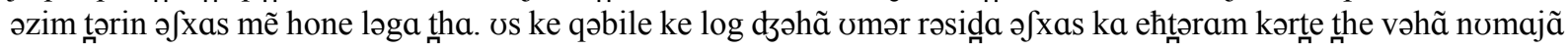
karkərdəgi dikhane valõ ko təqəd্] 
Table 10. The placement of adjunct before the correlative hypotactic themes

\begin{tabular}{|c|c|c|c|c|c|c|}
\hline \multicolumn{7}{|c|}{ English Source Text } \\
\hline \multirow[t]{2}{*}{$\mathbf{C L}$} & \multirow[t]{2}{*}{$\mathbf{N}$} & \multicolumn{4}{|l|}{ Theme } & \multirow[t]{2}{*}{ Rheme } \\
\hline & & Textual & & Adjunct & Topical & \\
\hline 5.1a & - & & & To crown it all & he & had taken two titles \\
\hline $5.2 \mathrm{a}$ & $1+2$ & and & & & --- & $\begin{array}{l}\text { had shown incredible prowess in two } \\
\text { inter-tribal wars. }\end{array}$ \\
\hline \multirow[t]{3}{*}{$5.3 \mathrm{a}$} & $1+2$ & And & & & Okonkwo & was still young, \\
\hline & $1 \times 2$ & so & & & & \\
\hline & $\alpha \times \beta$ & although & & & & \\
\hline $5.4 a$ & - & & & & he & $\begin{array}{l}\text { was already one of the greatest men of } \\
\text { his time. }\end{array}$ \\
\hline $5.5 \mathrm{a}$ & - & & & & Age & was respected among his people, \\
\hline $5.6 \mathrm{a}$ & $1+2$ & but & & & achievement & was revered. \\
\hline \multicolumn{7}{|c|}{ Urdu Target Text } \\
\hline \multirow[t]{2}{*}{$\mathbf{C L}$} & $\mathbf{N}$ & Theme & & & & Rheme \\
\hline & & Topical & Textual & Adjunct & Topical & \\
\hline $5.1 \mathrm{~b}$ & - & & & $\begin{array}{l}\text { In səb se bərh kər } \\
\text { jəh ke }\end{array}$ & vo & do ləqəb Ixtəajar kər tyoka tha \\
\hline $5.2 \mathrm{~b}$ & $1+2$ & & əor & & --- & $\begin{array}{l}\text { qəbaeli ke maben do dəõgõ mẽ naqabile } \\
\text { jəqin quvət-o-taqət ka muzahira kər } \\
\text { tyoka tha. }\end{array}$ \\
\hline $5.3 \mathrm{~b}$ & - & & & & Okonkwo & obhi dzovan tha \\
\hline $5.4 \mathrm{~b}$ & $1+2$ & & ləkın & & us ka Jumar & $\begin{array}{l}\text { əpne zəmane ke əzim tərin əðxas mẽ hone } \\
\text { ləga tha. }\end{array}$ \\
\hline $5.5 b$ & & $\begin{array}{l}\text { us ke qəbile ke } \\
\log \end{array}$ & dzəhã & & umər rəsida ə $\int x a s k a$ & ehtəram kərte the \\
\hline 5.6b & & & vəhã & & $\begin{array}{l}\text { nomajã karkərdəgi } \\
\text { dikhane valõ ko }\end{array}$ & toqədos əta kərte the. \\
\hline
\end{tabular}

The English clauses (5.1a), (5.2a), (5.3a) and (5.4a) carrying given information and continuous thematic progression are connected by the paratactic and hypotactic themes. Among these clauses, the clause (5.3a) incorporates three textual themes: (1) and indicating addition, (2) so indicating inference and (3) although indicating opposite correlation. These textual themes have not been translated into Urdu clause (5.3b) which looks an independent clause connected to another independent clause (5.4b) by paratactic theme of extension. The omission of textual themes creates ambiguity in meaning and function of Urdu clauses. The English thematic structures mean that as Okonkwo had taken two titles and had shown incredible prowess in two inter-tribal wars so; although he was in young age, yet he was already one of the greatest men of his time. On the contrary, the Urdu thematic structures mean that as Okonkwo was still young and energetic so; he was already one of the greatest men of his time. This ambiguity can be avoided by using two textual themes is lije agartfa (so although) in an appropriate translation choice e.g., In sab se barh kar jah ke vo do laqab Ixtajar kar tfoka tha avr

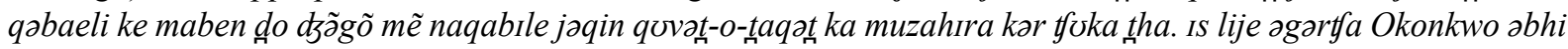
dzavan tha lakin os ka fumar apne zamane ke ozim tarin əfxas mẽ hone loga tha. The next English thematic structures in (5.5a) and (5.6a) carrying new information are connected by the paratactic theme. But their translated thematic structures in (5.5b) and (5.6b) carrying new information are connected by a correlative paratactic theme. This translation choice does not affect meaning but information flow differs because the information focus in the rheme (5.5a) is translated as an adjunct theme in (5.5b) carrying new information and placed at periphery position. The topical themes in (5.5b) and (5.6b) do not receive information from preceding thematic structures.

\section{Discussion}

After identifying grammatical realization of the paratactic and hypotactic thematic structures, this research justifies that English and Urdu use paratactic and hypotactic themes in different ways. Urdu can have multiple equivalents of English paratactic and hypotactic theme. Urdu also has its specific correlative hypotactic themes which although can be translated, yet are not common in English. The discussion regarding functional significance and thematic progression of the paratactic and hypotactic thematic structures concludes that the paratactic and hypotactic themes are always known as unmarked themes in English but in Urdu, the paratactic and hypotactic themes, specially wh-relative themes, are placed either as unmarked themes or as displaced themes. Moreover, the theme-rheme conflated to given-new units of information are similar in English and Urdu. 
The change of thematic progression patterns depends on the unmotivated displacement of paratactic, hypotactic and topical themes in Urdu. At the end, the analysis of the paratactic and hypotactic thematic structures in the English and the Urdu texts proves that Urdu translation choices of the English paratactic and hypotactic themes create ambiguity in conveying the exact information to the readers so; for the clarity of information and message, some other translations choices have been discussed in this piece of research.

\section{Conclusion}

In conclusion, some generalizations have been made after analyzing the English and Urdu paratactic and hypotactic themes. Firstly, both languages involve different grammatical realizations which affect the paratactic and hypotactic thematic relations during translation from English into Urdu. Secondly, grammatical changes cause functional and informational changes in terms of given-new information flow. Thirdly, despite having different syntactic structures, the translated target text includes ambiguous information due to unmotivated displacement of themes and rhemes. Even, it is noticed that some displaced themes convey not only ambiguous information but also change the overall background of the text. The most striking result is the difference in frequency of thematic progression patterns of the English and Urdu paratactic and hypotactic themes. The English source text maintains information flow with the highest frequency of constant thematic progression. On the other hand, the Urdu target text organizes information flow with the highest frequency of peripheral themes. The peripheral themes are actually not considered as the patterns of thematic progression so, it is obvious that the Urdu text lacks an appropriate thematic sequence and thematic progression.

At the end, it is suggested that if the translators translate a text according to the parameters of SFL, they will be able to interpret all the textual contents appropriately. This research clarifies the textual system of Urdu paratactic and hypotactic thematic structures in view of English in order to give awareness to the translators particularly and to enable the learners generally to comprehend the ambiguous translations. This research has some pedagogical implications as well to benefit the instructors how they can make the translations effective for the learners.

\section{References}

Achebe, C. (1994). Things fall apart. New York: Random House, Inc.

Alekseyenko, N. V. (2013). A corpus-based study of theme and thematic progression in English and Russian non-translated texts and in Russian translated texts. Unpublished PhD Dissertation, Kent State University.

Baker, M. (1992). In other words: A coursebook on translation. London: Taylor and Francis Limited. https://doi.org/10.4324/9780203327579

Bayer, J. (1996). Directionality and logical Form: On the scope of focusing particles and wh-in-situ. Dordrecht: Kluwer. https://doi.org/10.1007/978-94-017-1272-9

Butt, M., \& King, T. H. (2004). The status of case. In V. Dayal \& A. Mahajan (Eds.), Clause structure in South Asian Languages (pp. 153-198). Berlin: Springer Verlag. https://doi.org/10.1007/978-1-4020-2719-2_6

Butt, M., King, T. H., \& Roth, S. (2007). Urdu correlatives: theoretical and implementational issues (pp. 107127). In Proceedings of the LFG07 Conference, CSLI publication.

Eggins, S. (2004). An introduction to systemic functional linguistics. New York: Continuum.

Emilia, E. (2014). Introducing functional grammar. Bandung: Pustaka Jaya.

Fawcett, R. P. (forthcoming). The many types of theme in English: Their syntax, semantics and discourse functions. Sheffield. Equinox.

Gerot, L., \& Wignell, P. (1994). Making sense of functional grammar. Sydney: Stabler.

Halliday, M. A. K. (1994). An introduction to functional grammar. London: Edward Arnold.

Halliday, M. A. K., \& Matthiessen, C. M. I. M. (2004). An Introduction to Functional Grammar. London: Edward Arnold.

Halliday, M. A. K., \& Matthiessen, C. M. I. M. (2014). An introduction to functional grammar. London: Hodder Arnold. https://doi.org/10.4324/9780203783771

Halliday, M. A. K., \& Webster, J. J. (2014). Text linguistics: The how and why of meaning. London: Equinox Publishing.

Hasselgard, H. (2004). The role of multiple Themes is cohesion. In I. K. Aijmer \& A. B. Stenstrom (Eds.), 
Discourse patterns in spoken and written corpora (pp. 65-88). Amsterdam and Philadelphia: John Benjamin. https://doi.org/10.1075/pbns.120.06has

Herman, N. (2010). What's that got to do with anything? Coherence and the translation of relative clauses. The Journal of Specialized Translation, 13, 100-110.

Jalilifar, A. (2009). Thematic development in English and translated academic texts. Journal of Language \& Translation, 10(1), 81-111. https://doi.org/10.22425/jul.2009.10.1.81

Jiang, X. (2008). Parallel corpus in translation studies: An intercultural approach. Proceedings from The Symposium on Using corpora in Contrastive and Translation Studies, Lancaster University.

Ma, J., \& Wei, N. (2008). The great castby: A contrastive study of its two Chinese versions. Asian Social Science, 4(8), 32-35. https://doi.org/10.5539/ass.v4n8p32

Marzari, R. (2006). Arabic in chains: Structural problems and artificial barriers. Berlin: Varlag Hans Schieler.

Matthiessen, C. M. I. M., Teruya, K., \& Lam, M. (2010). Key terms in systemic functional linguistics. London \& New York: Continuum.

McCabe, A. M. (1999). Theme and thematic patterns in Spanish and English history text. Aston University, England.

Nida, E. A. (1982). Translating meaning. San Dimas, CA: English Language Institute.

O'Donnell, M. (2008). Demonstration of the UAM CorpusTool for text and image annotation (pp. 13-16). In Proceedings of the ACL-08: HLT Demo Session (Companion Volume). Association for Computational Linguistics. https://doi.org/10.3115/1564144.1564148

Quirk, R. et al. (1985). A contemporary grammar of the English language. London and New York: Longman.

Rahnemoon, S. N., Ahangar, A. A., \& Nourmohammadi, E. (2017). Thematic structure and translation: A case study of the translation of English news into Persian. Lingua, 194, 26-50. https://doi.org/10.1016/j.lingua.2017.05.003

Rørvik, S. (2003). Thematic progression in translation from English into Norwegian. Nordic Journal of English Studies, 2(2), 245-264. https://doi.org/10.35360/njes.136

Schmidt, R. L. (1999). Urdu: An Essential Grammar. London: Routledge.

Srivastav, V. (1991). The syntax and semantics of correlatives. Natural Language and Linguistic Theory, 9(4). https://doi.org/10.1007/BF00134752

Ullah, I. (1991). Bikharti Duniya. Lahore: Nigarshat Publications.

Van Huffel, J. (2007). The Hallidayan notion of theme in original and translated fiction texts in English and Dutch. Unpublished PhD Thesis, Universiteit Gent.

Ventola, E. (1995). Thematic development and translation. In M. Ghadessy (Ed.), Thematic development in English text (pp. 85-104). London: Pinter.

\section{Note}

THIS PAPER IS A PART OF THE RESEARCHER'S PHD DISSERTATION.

\section{Copyrights}

Copyright for this article is retained by the author, with first publication rights granted to the journal.

This is an open-access article distributed under the terms and conditions of the Creative Commons Attribution license (http://creativecommons.org/licenses/by/4.0/). 